\title{
Andragogy and N. F. S. Grundtvig revisited
}

\author{
By Clay Warren
}

Unusually for this journal, the editors here republish with permission an article which first appeared elsewhere some twenty years ago. It is in effect a case-history of Grundtvig's virtual absence (or at any rate the absence of direct consultation of his writings) in an historical cultural milieu where his presence would be highly relevant and productive, namely in the development of the theory and study of adult or lifelong education in the United States of America. The self-perpetuating unawareness (as the author perceives it) of this particular rich legacy of nineteenth-century European innovative thought is obviously attributable in part to the inaccessibility of Grundtvig's Danish writings and the paucity of reliable English-language translations and relevant editorial apparatus. The article is in effect a call both to American adult education scholars to incorporate Grundtvig in his proper place in the American reading of the modern history of western education, and to Grundtvig-scholars in Europe to furnish translated resources sufficiently authoritative and comprehensive to serve as a source and a tool for such a mission.

Clay Warren is Chauncey M. Depew Professor of Communication in The George Washington University in Washington, DC. Married to a Dane, he worked for two years in a Danish folkhighschool, and in 1993 visited Denmark to videotape interviews with prominent Grundtvig scholars, leaders in the folkhighschool world, folkhighschool principals, leaders in the sphere of Danish adult education, and the pastor then in charge of Vartov Church. These interviews resulted in Professor Warren's Democracy is born in conversations (1998).

The article 'Andragogy and N. F. S. Grundtvig: A Critical Link' was originally published in Adult Education Quarterly, Vol. 39, No. 4 (1989).

Twenty years ago, I proposed to make a contribution to at least two different fields - the adult education discipline and area studies on $\mathrm{N}$. F. S. Grundtvig - by summarising the ideas of major American philosophers of adult education, consolidating the educational philosophy of N. F. S. Grundtvig, comparing Grundtvig's philosophy of learning with the andragogical guideposts of the Americans, and checking for acknowledgement of Grundtvig's contributions to adult education. I discovered a number of interesting things along the way, which are available in the reprinted article (Warren 1989) that follows, and arrived at the inescapable conclusion that Grundtvig's philosophy of lifelong learning had been neither critically examined nor ack- 
nowledged by American adult education scholars who, at the time, were actively searching for philosophical guideposts for adult education.

This state of affairs was unusual for a disciplinary background, because academe (of which Grundtvig was highly critical) stresses the need for scholars to use primary sources. While Eduard Lindeman, often called the father of American adult education, was profoundly influenced by Grundtvig - and through a cross-checking of philosophical points and his own statements it is evident that he was - he clearly had not read any of Grundtvig's literary output and thus was influenced not by a primary source but entirely by secondary or tertiary sources. In this case, a secondary source would be scholars who had read Grundtvig and discussed his educational philosophy orally or in print, and a tertiary source would be the operational embodiment of Grundtvig's idea of a right-minded educational institution - the folkhighschool. So, it is perhaps both ironic and fitting that Lindeman was influenced not by Grundtvig's written heritage but by his living word (that concept so fundamental to Grundtvig's theological and pedagogical thinking alike; in this case, people discussing ideas with each other). After Lindeman's established baseline, second-generation important adult educators such as Malcolm Knowles quoted Lindeman (with no mention of Grundtvig), and third-generation adult educators such as Stephen Brookfield quoted Knowles and Lindeman (with Grundtvig nowhere in sight).

In the concluding lines of 'Andragogy and N. F. S. Grundtvig', I proposed a need to correct this situation, not only to give Grundtvig appropriate acknowledgement through primary reference documentation but also to give us the satisfaction of directly enjoying the workings of Grundtvig's mind. To make such a correction possible, of course, more of Grundtvig's educational writings would need to be available for non-Danish readers, and these readers (including scholars) would need to read Grundtvig.

Initial response to the article was strong. I received a number of letters from people around the world who said such things as "excellent points and high time they were made", "adult education is justly criticised for a kind of primary source fabrication", and "I learned a lot and now want to read Grundtvig; how can I find his work in English?"

Two decades later, I am delighted that Grundtvig-Studier wishes to give fresh currency to my article in a more defined context of Grundtvig studies. Naturally, the question arises: So, what has changed in the interim? To what extent are the twenty-year-old criticisms still valid? Unfortunately, the answer largely sustains the previous observations: 
Not enough has changed, although there is one bright spot on the recent horizon.

So far as American or American-related adult education scholars using or acknowledging Grundtvig are concerned, the situation generally is the same in 2009 as it was in 1989. There are always exceptions to a rule, and Grundtvig's writings were quoted numerous times in Schuster's 'Swedish-language folkhögskolor in Finland' (2007) which drew upon the work of Knudsen, Jensen and Lawson mentioned later in this piece. Most educators outside of Denmark, however, still seem not to have read Grundtvigian primary sources in translation (let alone in Danish), and are not quoting him in major books and articles produced on adult education, particularly American adult education. Instead, there is a citation train originating in a source which did not itself use the foundation of a primary source. For those who know the old ditty, it is reminiscent of "The House that Jack Built". It is still à la Brookfield quoting Knowles quoting Lindeman who lived (nonquotationally) in the house that Grundtvig built.

For example, one will not find an exploration of Grundtvig in a five-volume work by Jarvis and Griffin - Adult and Continuing Education: Major Themes in Education (2003) - designed to help teachers and students gain access to key thinkers in adult education and lifelong learning, and billed as the first comprehensive overview of the field. Although a stated purpose is to explore the development of Western adult education, there are only four pieces (of a total of 164) from the nineteenth century, and, as Rogers (2004) noted in a review of the book, the overarching perspective seems to be that adult education "arose as a tool of the Enlightenment (not so much in Grundtvig's meaning as in the post-modernist construction) [...] [and that it] is itself ruled by an ideology that reason controls human beings" (78). The editors acknowledge that this viewpoint is a narrow (even ethnocentric) approach to adult education, yet it guided their choices of material, which largely consist of pieces from Britain and America.

Similarly, in an earlier work - Adult Education and Continuing Education: Theory and Practice - Jarvis (1995) discussed andragogy and cited Lindeman and Knowles, but mentioned Danish folkhighschools only in passing with no citation or even recognition of Grundtvig. The same holds true with Twentieth Century Thinkers in Adult and Continuing Education (Jarvis 2001) with chapters on Lindeman (by Brookfield), Knowles (by Jarvis), and Houle (by Griffith), none of which references Grundtvig.

Wilson and Hayes (2000) published the 768-page Handbook of Adult and Continuing Education, a work sponsored by the American Association of Adult and Continuing Education and described by 
various reviewers as "monumental", an "indispensable resource", and a "definitive reference". Sixty leading authorities with diverse perspectives explore a wide variety of topics, including andragogy, Lindeman and Knowles, without a single reference to Grundtvig. In International Perspectives on Lifelong Learning (Istance, Schuetze and Schuller 2002), there is one sentence relevant to the illustrious Dane which seemingly should herald his importance to the subject: "Denmark in the nineteenth century showed the way, and under the leadership of Grundvig [sic] gave birth to lifelong learning for participatory democracy" (32). It is impossible to ignore the misspelling of his name.

Moreover, the same criticism made of Houle's work in 1972 (The Design of Education), in which he failed to include Grundtvig's work in a self-described "elaborate documentary study" on adult education and its guides to practice, must be applied to an even larger study The Literature of Adult Education: A Bibliographic Essay - published twenty years later (Houle 1992) that includes over 1200 books related to lifelong learning in an effort to help professionals find guidance to improve their adult education practices in all areas. Although Grundtvig's writing was excluded from both books that purportedly feature an exhaustive identification of the literature of adult education, Grundtvig was at least mentioned briefly in the earlier work but not at all in the latter. His name is conspicuously absent from a name index that lists some 1,242 individuals including Aristotle, Thoreau, Tolstoy and Swift who of course are tangentially related to adult education, at best. And this exclusion comes on top of a meagre two-page section on the history of folkhighschools in which the only quoted person is Lindeman, who says of an early study of Danish folkhighschools (Begtrup, Lund, and Manniche 1936): "Americans will still have difficulty in understanding the Danish movement, but [...] no one need now be satisfied with second-hand interpretation" (13). The irony of this observation begs the well-known Danish sense of humour.

A last but no doubt not final example: In a recent work on an important American activist adult educator named John Ohliger (Grace, Rocco, and associates 2009), yet again Grundtvig is not once acknowledged although Lindeman, Knowles, Brookfield, Stewart, Freire, Illich and others are all in there. Ohliger was a hearty critic of the systematising of adult education. As pointed out in the book, Ohliger wished to reinstall social democracy as the key to learning and was inspired by educators such as Lindeman, whom he quoted from a speech to the New York City Adult Education Association (adding that the words were "sadly prophetic"): "There is ultimate danger that the professional leadership in this movement [adult education] might get itself in the same box as has the professional leadership in our conven- 
tional education" (4). This position resoundingly echoes Grundtvig's criticisms of Danish education, warning that teachers in folkhighschools should not become institutionalised but be regularly rotated back to "life". The Professionalization of Adult Education by Grace and colleagues would have benefited by touching base historically with another probable Grundtvigian influence on Lindeman.

There has been some progress on secondary fronts, including The Land of the Living (Borish 1991), a book about Danish folkhighschools; Democracy Is Born in Conversations (Warren 1998), discussed below; and even a translation into Japanese of 'Andragogy and N. F. S. Grundtvig' (Warren 2005) for publication in the journal of Japan's folkhighschool movement. There continues to be an output of articles about Grundtvig, particularly from non-American sources, including those regularly found in Grundtvig-Studier, and in works such as Heritage and prophecy: Grundtvig and the English-speaking world (Allchin, Jasper, Schjørring and Stevenson 1993), N. F. S. Grundtvig: An Introduction to his Life (Allchin 1997), Thinkers on Education, Vol. 2 (Morsy 1997), Grundtvig in international perspective (Allchin, Bradley, Hjelm and Schjørring 2000), Grundtvig's educational ideas in Central and Eastern Europe and the Baltic States in the twentieth century (Kulich 2002), and Education for the People: Concepts of Grundtvig, Tagore, Gandhi and Freire (Bhattacharya 2008).

Also, there were several organisations - one based in the U.S. and the other in Denmark - that published material related to Grundtvig. Between 1976 and 1998, Option, the journal of the Folk Education Association of America (FEAA), published 53 volumes in which a number of articles directly or indirectly related to Grundtvig were printed. Although FEAA has been dormant and the journal out of print for a number of years, there is a current effort to revive it as a chapter of the Danish-based Association for World Education; and a book, Lifted by the Heart (Spicer, in press), intended to provide highlights of the journal, is scheduled for imminent publication. This work, among other things, will provide an introduction to Grundtvig, his educational ideas (focusing on the folkhighschool model), and the 125 years of andragogical practice in America inspired by these ideas. Moreover, in the 1990s, Nornesalen: Center for Research on Life Enlightenment and Cultural Identity, undertook a project to study Grundtvig's impact outside of Denmark. This now-defunct initiative published such studies as Grundtvig's educational ideas in Japan, the Philippines, and Israel (Zøllner 1994), Enlightenment in an international perspective (Zøllner and Andersen 1995), and Canada and Grundtvig (Bugge 1999). This last work, for example, mainly looks at folkhighschoolinspired initiatives in Canada. 
In 1989, when 'Andragogy and N. F. S. Grundtvig' was published, in terms of available book-length publications there were two English compilations of Grundtvig: Knudsen's Selected writings: N. F.S. Grundtvig (1976), with 34 of 184 pages devoted to Grundtvig's educational prose, and Jensen and colleagues' A Grundtvig anthology: Selections from the writings of N. F. S. Grundtvig (1984), with the majority of the book devoted to Grundtvig's output on mythology, religion and poetry, and only the occasional piece on education, such as "The school for life".

Lawson's N. F. S. Grundtvig: Selected educational writings joined this select group in 1991. Half of this short book includes work previously published and half includes new work, including the significant "The Danish Four Leaf Clover" which was not found in Knudsen although it was mentioned as important in "The Danish High School" - a writing included in both the Knudsen and Lawson compilations. So, some progress was made in this new compilation, although we are still only talking some 56 pages. Both Knudsen's and Jensen's books are now out of print, and Lawson's is hard to come by for a reader living in the United States.

Fortunately, the Centre for Grundtvig Studies, University of Aarhus, which has evolved to become a major institute devoted to Grundtvig-related research, conferences, seminars and publications, established an English translation project on the heels of committing itself to a "reassessment of the Grundtvig legacy" in 1990. The first volume in a planned series of translations appeared in 2008, somewhat delayed by a decision to extend the volume with a 252-page Index designed to help readers' understanding of the broader context of works written in the 1800s. This 597-page book-N. F. S. Grundtvig: A life recalled. An anthology of biographical source-texts (Bradley 2008) - is compiled in three parts: Grundtvig's memoirs (his own writings), memoirs of Grundtvig (others' writings about him), and the Index (along with a prologue of significant dates in Grundtvig's life). While the core of the book is a translation of Grundtvigs Erindringer og Erindringer om Grundtvig (Johansen and Høirup 1948 and 1983), each piece by or about Grundtvig is furnished with a brief introduction setting the excerpt in context.

It is a monumental, long-overdue effort to make some of Grundtvig's writings available to a broader audience. As Kelstrup (2009) remarked in a review of the book:

A tool has been delivered to all who concern themselves with Grundtvig in the international world. It is only to be wished that the momentum will be kept up. By all means let there be added more tools 
to the English Grundtvig toolbox. And by all means at Bradley's high standard (247, in authorised translation from the Danish).

The text selections probably will be of greatest resonance to those interested in history and religion; however, putting together some assessments in slightly different chronology, the reader clearly can see how Grundtvigianism, "born within his own lifetime ... [was] pursued with an awe-inspiring fervour and doggedness" (Bradley 2008, 32, 31). Grandtvig was an intellectual colossus who applied his remarkable abilities over an extraordinarily wide field, who systematically tried to influence the society in which he lived, and who was keenly aware of his effect on the times as well as interested in what his legacy might be. Bradley's book lends support to the contemporary appreciation of this legacy, and adult education worldwide will be further well served when the project extends itself to Grundtvig's andragogical writings.

\section{Bibliography}

\section{Works by Grundtvig}

Bradley, S. A. J. (trans. and ed.) (2008), N. F. S. Grundtvig: A life recalled. An anthology of biographical source-texts, Aarhus.

Jensen, N. L., Michelsen, W., Albeck, G., Toftdahl, H. and Thodberg, C. (eds) (1984), A Grundtvig anthology: Selections from the writings of $N$. F. S. Grundtvig (1783-1872), Cambridge; Viby.

Johansen, S. and Høirup, H. (eds) (1948; reprint 1983), Grundtvigs Erindringer og Erindringer om Grundtvig, Copenhagen; repr. Copenhagen.

Knudsen, J. (trans. and ed.) (1976), Selected writings: N. F. S. Grundtvig, Philadelphia.

Lawson, M. (ed.) (1991), N. F. S. Grundtvig: Selected educational writings. Skive.

\section{Works by others}

Allchin, A. M. (1997), N. F. S. Grundtvig: An introduction to his life and work, Aarhus.

Allchin, A. M., Bradley, S. A. J., Hjelm, N. A. and Schjørring, J. H. (eds) (2000), Grundtvig in international perspective: Studies in the creativity of interaction, Aarhus.

Allchin, A. M., Jasper, D., Schjørring, J. H. and Stevenson, K. (eds) (1993), Heritage and prophecy: Grundtvig and the English-speaking world, Aarhus.

Begtrup, H., Lund, H. and Manniche, P. (1936), The folk high schools of Denmark and the development of a farming community ( $3^{\text {rd }}$ ed.), Oxford.

Bhattacharya, A. (2008), Education for the people: Concepts of Grundtvig, Tagore, Gandhi and Freire, Kolkata. 
Borish, S. M. (1991), The Land of the Living: The Danish Folk High Schools and Denmark's Non-violent Path to Modernization, Nevada City, CA.

Bugge, K. E. (1999), Canada and Grundtvig, Vejle.

Grace, A. P., Rocco, T. S. and Associates (2009), Challenging the professionalization of adult education: John Ohliger and contradictions in modern practice, San Francisco.

Houle, C. O. (1992), The literature of adult education: A bibliographic essay. San Francisco.

- (1972), The design of education, San Francisco.

Istance, D., Schuetze, H. G. and Schuller, T. (eds) (2002), International perspectives on lifelong learning, Philadelphia.

Jarvis, P. (1995), Adult and continuing education: Theory and practice, New York.

- (ed.) (2001), Twentieth century thinkers in adult and continuing education $\left(2^{\text {nd }}\right.$ ed.). Sterling, VA.

Jarvis, P. and Griffin, C. (eds) (2003), Adult and continuing education: Major themes in education, 5 vols. London.

Kelstrup, E. (2009), 'Gedigen oversættelse af Grundtvig', Dansk Kirketidende 8, 161. årgang, 246-247.

Kulich, J. (2002), Grundtvig's educational ideas in Central and Eastern Europe and the Baltic States in the twentieth century, Copenhagen.

Morsey, Z. (ed.) (1997), Thinkers on education, Vol. 2, Lanham, MD.

Rogers, A. (2004), 'Book Review of Adult and continuing education: Major themes in education', International Review of Education, 50 (1), 77-79.

Schuster, K. (2007), 'Swedish-language folkhøgskolor in Finland: Ethnonationalism, language, and adult education in the nineteenth century' in K. Schuster and D. Witosky (eds), Language of the land: Policy, politics, identity in Studies in the history of education series), Charlotte, NC, 25-53.

Spicer, C. (in press), Llfted by the heart: Writings from Option-the journal of the Folk Education Association of America, Nyack, NY.

Warren, C. (2005), 'Andragogy and N. F. S. Grundtvig' (Japanese transl. of 'Andragogy and N. F. S. Grundtvig: A Critical Link', 1989), Heimdal (Grundtvig Society of Japan for Folkhighschool Movements Journal), 26 (1), 6-14.

- (ed.) (1998), Democracy is born in conversations: Recreating N. F.S. Grundtvig for lifelong learners around the world, Nyack, NY.

- (1989), 'Andragogy and N. F. S. Grundtvig: A Critical Link', Adult Education Quarterly, 39 (4), 211-223.

Wilson, A. L. and Hayes, E. R. (2000), Handbook of adult and continuing education, New York.

Zøllner, L. (1994), Grundtvig's educational ideas in Japan, the Philippines, and Israel, Vejle.

Zøllner, L. and Andersen, A. M. (1995), Enlightenment in an international perspective, Vejle. 